\title{
Parental Involvement on Child's Education during Pandemic Times: A Qualitative Exploration
}

\author{
Afreen Khan ${ }^{1}$, Sana Irshad ${ }^{2}$ \\ ${ }^{1}$ Research Scholar, Dept. of Psychology, Aligarh Muslim University, Aligarh (India) \\ ${ }^{2}$ Research Scholar, Dept. of Psychology, Aligarh Muslim University, Aligarh (India)
}

Corresponding Author: Sana Irshad

\begin{abstract}
The main objective of the present research is to study the influence of parental involvement on child's education during the pandemic times. As a result of COVID-19, several countries applied emergency plans, for instance lockdown and school closures. The Parental association is very essential in education and has become spirited in the world of education. It will benefit to increase child's social interactions as well as stimulate a sense of self-esteem and self-efficacy. Thus, the current study intended to examine parental involvement in their children's learning during the lockdown and school closures in 2020. Hence, the study is especially planned to form the association among parental involvement and child's concert in education during pandemic.
\end{abstract}

Keywords: COVID-19, child's education, parental involvement.

\section{INTRODUCTION COVID-19:}

As the COVID-19 virus spreads, governments had put into practice various emergency strategies to stop or sluggish the transmission of this deadly virus. These strategies or plans include closures of colleges, schools or universities, malls, parks etc, nationally, regionally and in a targeted manner to stop the direct interaction among individuals for any activity and demanding people to maintain physical distance and stay at home and even imposing full lockdown in some countries. These disturbances in the normal life such as home schooling, social isolation and other have affected students, both academically as well as mentally which in turn was affecting the mental health and well being of the students, educators and families.

Various academic measures have been employed to reduce these learning losses and mobilize varied forms of online learning and educational resources to ensure the continuity of teaching and learning. As a result, the need for digital technology has increased significantly during the epidemic, although this reinforcement means a challenge for educators, families, and students to assure the continuity of home learning. Since, majority of schools and educators were not used to online teaching, it is challenging to change immediately. Despite of the available technical resources, the proficiency of educators and school's effective use of digital equipments required to be improved. Other problems include lack of access by students to internet and technology, increasing assignments, homework and narrow opportunities to obtain deep interpretation from educators when necessary. Therefore, online education resulted in increasing level of stress for students and families.

\section{Parental Involvement}

The COVID-19 pandemic and the related measures have also affected parental involvement or behaviour. The shutting down of schools around the world in relation to COVID-19 required parents to play basic educational role to support their children in academic activities and to move 
to remote and often virtual world of online education, which posed many difficulties for families. With regard to parents of children studying in special schools, the loss of education as well as provision of treatment, has added another layer of complication unique to this group.

Holloway, Yamamoto, Suzuki, and Mindnich (2008) stated parent involvement as "an activity involving broad variety of behaviours ranging from discussing as the initiation of home-based behaviours like monitoring, help in homework, and cognitive stimulation in the home environment to school-based activities such as attending school events and communicating with teachers".

Parental involvement at home setting is defined by Sheldon's (2002) as "parentchild interactions on school-related or other learning activities and represents the direct investment of a parent's resources in her or his child's education".

Reynolds (1992, p. 1121) describe parental involvement as "any communication between a parent and child that may contribute to the child's development or direct parent participation with a child's school in the interest of the child.

Parents have mixed opinions towards remote learning. Some parents feel that it is more connected with their children's studies, while others feel that this is an extra load (Selwyn et al., 2011). Sorensen's (2012) reported that the most challenging and beneficial aspect of online education for parents is to keep their children to complete their work on time and to interact with their children's online educators. On the other hand, schools and educators also don't have sufficient supervision to enhance the experience of parental participation, especially in the case of effective use of technology.

Various studies reported that involvements of parents in their child academic activities were found to be positively correlated with enhanced academic performance and educational success. Specifically, children showed higher academic performance when parents are more involved in their educational activities as compared to those children whose parents have lesser involvement in their education. Not only researchers noticed the impact of parental involvement on improved academic performance but policy makers also noted the same and hence they incorporated their works to enhance parental participation into wide educational policy initiatives.

\section{Barriers to parental involvement in relation to remote learning-}

From the perspective of parents, various barriers to remote and home learning have been recognized for instance,

1. Personal barriers,

2. Technical barriers,

3. Financial barriers and

4. Logistic barriers.

i) Personal barriers included low-tech proficiency to help their children's access to online education and resources used in this context.

ii) Technical barriers included lack of sufficient internet access or tools to properly track learning activities.

iii) Financial barriers included the inability to afford better technical equipment and internet access.

Iv) Logistic barriers included the perception of parents that online education does not meet up the students personal needs/learning pace and recognized it as not a successful alternative for the face to face learning.

Although there are obstacles, parental participation in their children's education has increased during the period of lockdown. The publications emphasized how parents of children's of all ages from elementary to middle school felt closer to their children's educational activities by recognizing a deeper understanding of their learning activities and hence providing opportunities to add more to their learning. In addition, majority of parents especially the parents of younger students recognize 
that situation of studying at home has improved the relationships between parents and teachers and enhanced their appreciation towards teachers. This view has also been recognized by educators.

\section{REVIEW OF LITERATURE}

Haller and Novita (2021) in a study showed that during the time of lockdown, perceived support and capabilities of educators were significant factors for parent's satisfaction of school.

Lawrence and Fakuade (2021) in a study revealed that there exist positive and significant relationship between parental involvement and adolescent's commitment to online education during covid-19 lockdown. While Spinelli and colleagues (2021) reported that during pandemic, parents with low level of stress show more concerned towards their children learning activities as compared to parents with high level of stress. On the other hand Dong and colleagues (2020) showed that most of the parents believe that it is necessary to accompany their children at least once a day in online learning activity.

\section{CONCLUSION}

The state of health emergency associated with the COVID-19 pandemic and the ensuing quarantine restrictions have disrupted our daily life and lifestyle in a subtle way. Especially the families having children had to countenance a unique and totally new condition. Suddenly, the parents become the only reference point for their children. Due to closure of schools and colleges, the academic life of children had also affected. To ensure the continuity of learning among children varied forms of online learning and educational resources were employed. Due to this, the need for digital technology has enhanced drastically during the pandemic which creates a considerable challenging situation for families, students and educators as they were not used to online learning. Despite of the available technical equipments, the skills and effective use of digital equipment needed to be improved. Hence, online learning resulted in high level of stress among students, educators and families. Despite of the hurdles, parental participation had significantly increased during the period of lockdown. Parents of children of all ages have more understanding of their children learning activities and hence providing more opportunities to add more to their learning, and as they spent more time together taking part in household work together parents and hence felt more connected with each other which also led to stronger relationship between them.

\section{Suggestions}

The COVID-19 disease also carries the feelings such as stress, anxiety and ambiguity to children of all ages. Although all children deal with these feelings in distinct ways, if the child has faced closure of school, abolition of events or split-up from friends, they will definitely need more love and support now than ever. These are ways through which we can help children to deal with Pandemic times:-

Parents should do quiet and effective discussion with their children about corona virus disease. They should ask their children if they are concerned about corona virus or not feeling good so that their parents can help. Parents can remind their children that they can do many effective things to protect themselves and others, and to better control their environment: wash their hands frequently, do not touch their face and maintain physical distance.

Parents must ensure that there is a one-day schedule which can comprise of game time when children can play on their mobile and can also talk to their friends. With this they should also set aside nontechnical time and time to help with housework.

As there is lots of wrong information about corona virus disease around, parents should find out what their child is listening to or what he or she thinks is true. But it is not sufficient to just inform children correct facts, because if they find something wrong 
and parents don't understand their thinking and directly resolve the misunderstanding, they may use the old information in combination with new information which was given them by their parents. So, it is important for parents to find out what their child already knows and from there, put them on the right path.

Children trust their parents to ensure safety and security. Of course, parents are also stress and their child makes emotional sign from them, parents should manage their stress, anxiety and do not over share their worries with children (UNICEF, 2020).

Measures are also needed to improve the educator's capability and skills to support children's learning at home. Educators should be provided with professional development training to enhance their ability and can respond quickly to the challenges brought by online learning.

In order to enhance the efficiency of children's autonomy and self-regulating learning ability, educators should also invent challenging task suitable for enhance children's development, support students, make students responsible for their own learning and adopt continuous assessment practices that are susceptible to the online learning situation to assess students and adjust or modify the learning preferences during class suspension.

\section{Acknowledgement: None}

\section{Conflict of Interest: None}

\section{Source of Funding: None}

\section{REFERENCES}

1. Dong, C., Cao, S., \& Li, H. (2020).Young children's online learning during COVID-19 pandemic: Chinese parents' beliefs and attitudes. Children and youth services review, 118, 105440.

2. Garbe, A., Ogurlu, U., Logan, N., \& Cook, P. (2020). COVID-19 and remote learning: Experiences of parents with children during the pandemic. American Journal of Qualitative Research, 4(3), 45-65.
3. Holloway, S. D., Yamamoto, Y., Suzuki, S., \&Mindnich, J. D. (2008). Determinants of Parental Involvement in Early Schooling: Evidence from Japan. Early Childhood Research \& Practice, 10(1), n1.

4. Haller, T., \&Novita, S. Parents' perceptions of school support during COVID-19: What satisfies parents?.In Frontiers in Education (p. 283).Frontiers.

5. Jaiswal, S. K. A study of academic performance and academic self concept of secondary school students in relation to their perception and expectation of parental involvement.

6. Lau, E. Y. H., Li, J. B., \& Lee, K. (2021). Online learning and parent satisfaction during COVID-19: Child competence in independent learning as a moderator. Early Education and Development, 32(6), 830842.

7. Lawrence, K. C., \&Fakuade, O. V. (2021). Parental Involvement, Learning Participation and Online Learning Commitment of Adolescent Learners during the COVID-19 Lockdown. Research in Learning Technology, 29.

8. Morelli, M., Cattelino, E., Baiocco, R., Trumello, C., Babore, A., Candelori, C., \&Chirumbolo, A. (2020). Parents and children during the COVID-19 lockdown: The influence of parenting distress and parenting self-efficacy on children's emotional well-being. Frontiers in Psychology, 11, 2584.

9. O’Connor, U., Bates, J., Finlay, J., \& Campbell, A. (2021). Parental involvement during COVID-19: Experiences from the special school. European Journal of Special Needs Education, 1-14.

10. Perry, N. E., VandeKamp, K. O., Mercer, L. K., \& Nordby, C. J. (2002). Investigating teacher-student interactions that foster selfregulated learning. Educational Psychologist, 37(1), 5-15. https://doi.org/10.1207/S15326985EP3701_ 2

11. Perry, N. E., \&VandeKamp, K. J. (2000). Creating classroom contexts that support young children's development of self regulated learning. International Journal of Educational Research, 33(78), 821-843. https://doi.org/10.1016/S08830355(00)00052-5

12. Ribeiro, L. M., Cunha, R. S., Carvalho, M., \& Vital, M. L. (2021). Parental Involvement 
during Pandemic Times: Challenges and Opportunities. Education Sciences, 11(6), 302.

13. Reynolds, A. J. (1992). Comparing measures of parental involvement and their effects on academic achievement. Early Childhood Research Quarterly, 7(3), 441462.

14. Spinelli, M., Lionetti, F., Setti, A., \&Fasolo, M. (2021). Parenting stress during the COVID-19 outbreak: Socioeconomic and environmental risk factors and implications for children emotion regulation. Family process, 60(2), 639-653.

15. Sorensen, C. (2012). Learning online at the K-12 level: A parent/guardian perspective. International Journal of Instructional Media, 39(4).

16. Selwyn, N., Banaji, S., Hadjithoma-Garstka, C., \& Clark, W. (2011). Providing a platform for parents? Exploring the nature of parental engagement with school learning platforms. Journal of computer assisted learning, 27(4), 314-323.

17. Sheldon, S. B. (2002). Parents' social networks and beliefs as predictors of parent involvement. The elementary school journal, 102(4), 301-316.

18. Topor, D. R., Keane, S. P., Shelton, T. L., \& Calkins, S. D. (2010). Parent involvement and student academic performance: A multiple mediational analysis. Journal of prevention \& intervention in the community, 38(3), 183-197.

19. UNICEF (2020) https://www.unicef.org/ coronavirus/6-ways-parents-can-supporttheir-kids-through-coronavirus-covid-19

How to cite this article: Khan A, Irshad S. Parental involvement on child's education during pandemic times: a qualitative exploration. Galore International Journal of Applied Sciences \& Humanities. 2021; 5(4): 2226. DOI: https://doi.org/10.52403/gijash. 20211005 